\title{
Process of Implementation of International Financial Standards (IFRS)
}

\author{
Irena HONKOVÁ \\ University of Pardubice, Pardubice, Czech Republic \\ irena.honkova@upce.cz
}

\begin{abstract}
This paper is concerned with the implementation of International Financial Reporting Standards (IFRS) in the Czech Republic. It was written as a reaction to constantly increasing number of businesses implementing IFRS. In order to ascertain the methods selected by such companies for IFRS implementation, I carried out my own research based on semi-structured interviews. The aim of this research was to determine the individual stages of implementation, which would be helpful for business anticipating IFRS implementation. Generalization of the individual interviews revealed that the process of IFRS implementation may be divided into four stages: project preparation, opening stage, trial operation and adaptation operation. The most important thing in the initial stage is to create a project plan. The opening stage contains preparation of the areas affected by the implementation and the changes in the information system; the output of this stage consists in draft statements or a financial statement. In the third stage, trial operation is launched and tested and errors are eliminated; the result is an opening balance sheet. The final stage of adaptation operation includes inspection, evaluation and corrections of possible errors. IAS/IFRS implementation is a multi-stage process, which is time-consuming and demanding in terms of qualified staff and funds.
\end{abstract}

Keywords: International Financial Standards, IFRS, International Accounting Standards, IAS, IAS/IFRS Implementation.

\section{Introduction}

International accounting convergence is a highly complex process that began decades ago, emphasized globalization being the main factor that determined setters, professional bodies, investors to become aware of the importance of completing this process, namely the development and implementation of a common set of standards covering all areas of financial reporting. [11]

There are a number of business entities making financial statements in compliance with International Financial Reporting Standards or International Accounting Standards (hereinafter referred to as IAS/IFRS). [10]

Such businesses have experience with the implementation of IFRS principles in order to prepare financial statements in compliance with the said standards. This 
experience is very valuable because IAS/IFRS deal with the individual areas of accounting only or directly determine the targeted status only.

IFRS 1 First-time Adoption of International Financial Reporting Standards also does not provide specific methods and is based on the transition from GAAP (Generally Accepted Accounting Principles) to IFRS, not on the transition from national accounting regulations. [12]

IFRS 1 aims at: recognizing the assets, liabilities and shareholders equities in conformity with IFRS requirements, ending the recognition of some elements as assets or liabilities if the IFRS do not allow this recognition, reclassifying all the assets, liabilities and components of shareholders equities in conformity with IFRS, revising assets and liabilities evaluations in conformity with IFRS requirements. [6]

In reaction to the said facts, I carried out my own research of businesses proceeding in compliance with IFRS, aimed at the determination of specific methods of IFRS implementation. The given information should be of assistance to businesses anticipating IAS/IFRS implementation.

\section{Statement of Problem}

Economic globalization is under way in Europe, and in consequence of this, the need of harmonization of accounting is growing. In 2000, the European Commission decided that IAS (IFRS) will serve as the tool for regulation of European accounting. [7]

Since 2003, International Financial Reporting Standards (IFRS) have been gradually substituting International Accounting Standards (referred to as "IAS"). [14] IAS, which have not been substituted by IFRS yet, are still valid; therefore, the accounting standards are hereinafter referred to as "IAS/IFRS".

The duty to make financial statements in compliance with IAS/IFRS has been imposed on businesses with publicly subscribed shares by Section 19a of Act No. 563/1991 Sb. since 1 January 2005.

Member States of the EU may extend this regulation further to unquoted companies and/or individual financial statements. [4]

IFRS are annually published by the International Accounting Standards Board (IASB) in the form of a book including all the standards and their interpretations. The interpretations, referred to as "SIC" and "IFRIC", aim to clarify certain provisions of specific standards. The interpretations also react to new circumstances which were not included in the standards at the time of their creation. [5]

However, only standards approved by the Accounting Regulatory Committee, assisted by EFRAG (European Financial Reporting Advisory Group) and published in the Official Journal, are mandatory. [2]

Standards regulated in this way by the law of the European Union are valid in the whole of the European Union without the necessity of their transposition into national law. [8] 
Besides IAS/IFRS, there is the Conceptual Framework for Financial Reporting, which is not a standard of its own accord, but forms a necessary base for the preparation and understanding of the individual standards.

The Conceptual Framework outlines the aim, users, basic prerequisites, qualitative characteristics and contents, and the method of recognition and appraisal of the basic elements of a financial statement. The Conceptual Framework does not revoke or substitute any IAS/IFRS.

The purpose of the Conceptual Framework is to assist in the preparation of future IFRS and in the review of existing IAS/IFRS; it should serve as a basis for making national accounting standards; it should help persons making financial statements, auditors and users in their work, i.e., in IFRS application, evaluation of financial statements and interpretation of information contained in financial statements in compliance with IFRS. [9]

Most of the standards are divided into four main parts: definitions of terms referred to in the standard, methods of appraisal, criteria for recognition (stating) of items in financial statements, and publishing requirements. Some standards provide two possibilities of accounting treatment of the same problems. Such possibilities are designated as the "Basic Solution" and the "Permitted Alternative" or by the names of the permitted models. [14]

The experience of passing to IFRS in countries with economies in transition reveals certain problems associated above all with the same approach to the implementation of global reforms of national accounting systems. Current issues of transition to IFRS require attention and solution of internal problems of enterprises, which are defined by current management objectives and they include lack of qualified personnel, lack of collection of information (software) and increase the number of reporting packages (IFRS reporting and national standards). [17]

\section{Costs and benefits of I/AS/IFRS}

The costs associated with the IAS/IFRS implementation have been determined by the Institute of Chartered Accountants in England and Wales [5] as follows: the establishment of a project team, training of other employees, such as IT staff, internal audit and management, training of staff, external technical advice, tax advice, software and information systems changes, communications with third parties, external audit costs, renegotiating debt covenants and other external data requirements.

Besides the requirements for the IAS/IFRS implementation (costs and time) there are other facts burdening implementing businesses in terms of legislation. Businesses that still keep their accounts according to CAS should be prepared for them.

Based on the experience gained form the first implementation and application of IFRS, the transition economy countries singled out the main shortcomings of the process of applying IAS/IFRS in accounting and financial reporting: lack of standardized requirements for the application of national financial reporting standards and IAS/IFRS, lack of qualified specialists, availability of independent audit and 
professional organizations of accountants and auditors, availability of regulations concerning the mechanism of IAS/IFRS implementation, small and medium-sized enterprises. [17]

Oremusová [10] defines the general benefits of the international accounting standards as follows: easier access to foreign capital markets, higher credibility of foreign companies on domestic capital markets, global comparability of financial data, increased transparency, greater clarity due to „common accounting language”, simpler regulation on capital markets, lower influence of accounting standards by political pressures.

The gradual implementation of IAS/IFRS as accounting basis will increase an entity immediate expenses (for instance, costs for staff training, for the services of authorized evaluators, for software, for the preparation of accounting policies necessary for the application of IFRS, auditing financial statements etc.), but the advantages of presenting financial reporting based on these will be significant not only for the entities themselves, but also for other parties involved, advantages such as: it ensures transparency and comparability of financial reporting, credibility, better rate of information for investors and cheaper access to capital markets. [13]

International Accounting Standards have an important role in developing countries. [16]

\section{Description of the Research}

During the year 2016, 16 persons concerned with IAS/IFRS implementation in the Czech Republic were addressed in the form of a semi-structured interview.

Between September and December 2015, 24 respondents, who address the issue of the IAS/IFRS in the Czech Republic, were interviewed by means of semi-structured interview. Their function in the IAS/IFRS, the sector of their activity and information on the placement of their company shares on the stock exchange are included in the Table 1. Interviews' records including contacts are available.

Table 1. Research.

\begin{tabular}{|c|c|c|}
\hline Function & CZ-NACE sector classification & Stock Exchange \\
\hline Auditor & agriculture, forestry, fisheries & in preparation \\
\hline Auditor & $\begin{array}{c}\text { professional, scientific and technical } \\
\text { activities }\end{array}$ & no \\
\hline Auditor & $\begin{array}{c}\text { professional, scientific and technical } \\
\text { activities }\end{array}$ & no \\
\hline Auditor & $\begin{array}{l}\text { professional, scientific and technical } \\
\text { activities }\end{array}$ & no \\
\hline Auditor & manufacturing industry & no \\
\hline Auditor & $\begin{array}{l}\text { professional, scientific and technical } \\
\text { activities }\end{array}$ & no \\
\hline Project manager & finance and insurance & PSE \\
\hline
\end{tabular}




\begin{tabular}{|ccc|}
\hline Project manager & manufacturing industry & PSE \\
\hline Project manager & finance and insurance & no \\
\hline Accountant & manufacturing industry & no \\
\hline Accountant & manufacturing industry & $\begin{array}{c}\text { Frankfurt Stock } \\
\text { Exchange }\end{array}$ \\
\hline Accountant & transport and storage & $\begin{array}{c}\text { Luxembourg Stock } \\
\text { Exchange }\end{array}$ \\
\hline Accountant & water supply & no \\
\hline Accountant & finance and insurance & no \\
\hline Accountant & manufacturing industry & no \\
\hline Accountant & production and distribution of energy & no \\
\hline
\end{tabular}

The persons were asked about the process of IAS/IFRS implementation. Owing to the individual positions, the individual persons expressed themselves either on the implementation project or on the individual accounting adaptations.

10 persons were concerned with IAS/IFRS implementation as a project and 6 persons expressed themselves directly on accounting adaptations. The persons had to describe phases of IAS/IFRS implementation and ask about a question "How long was the process of implementation?"

The methods of implementation presented in the Results of the Research were created by generalization.

\section{Results of the Research}

As results from the research performed, the project of IAS/IFRS implementation has four main stages: project preparation, opening stage, trial operation, and adaptation operation, as given in Fig. 1

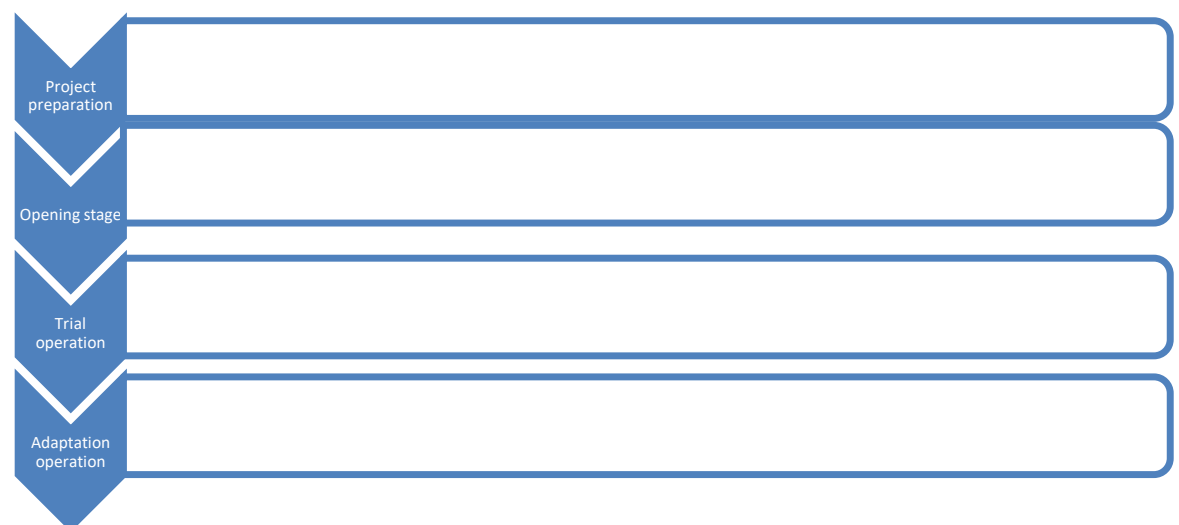

Fig. 1. Stages of IAS/IFRS Implementation. 
The first stage of the project, project preparation (Fig. 2), is preceded by the decision to implement IAS/IFRS; the above-mentioned legislative requirement is not the only reason for this. There are more reasons for businesses to implement IAS/IFRS, e.g. the requirements of their business partners. Businesses which have decided to implement IAS/IFRS due to bigger transparency, which is considered by them as a competitive advantage, are not exceptional.

Availability of information is crucial during project preparation. Three of the interviewed respondents got a manual and an application from the parent company in the group. The remaining respondents collected information by training key employees and from external counsellors. The aim was to ascertain the initial and the target statuses, which differed in the differences between CAS and IFRS (GAAP and IFRS in one case). The partial steps consisted in the definition of the areas where accounting transactions must be recorded in a different way. The determination of significance limits was an important aspect.

The preparatory stage resulted in a project plan containing a time schedule of activities and determination of problem-solving teams containing internal employees and external counsellors.

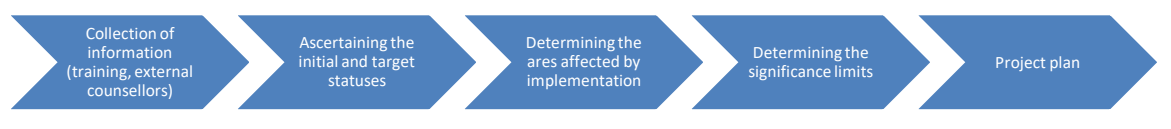

Fig. 2. Stage 1 - Project Preparation.

The second, opening, stage (Fig. 3) contained several partial steps.

At first, the individual accounting elements had to be defined from the perspective of IAS/IFRS and short-term and long-term assets and liabilities had to be classified.

Thus, assets were re-classified, newly appraised and the method of their depreciation changed. Liabilities were re-classified from the perspective of their being long-term or short-term. The research showed that businesses rather classified liabilities as short-term in order not to have to appraise them on the basis of their current value. Certain differences appeared also in the area of revenues and costs. Owing to the different concept, reserves changed and conditional liabilities developed; changes in retained earnings and in deferred tax were noted. It was necessary to substantially re-classify financial leasing and to recognize goodwill.

During the second stage, all the employees affected by the implementation were trained.

The Czech chart of accounts had to be adapted or an IFRS chart of accounts had to be opened; a sufficient number of analytics and transmission cross-walks had to be set 
up. It was crucial to ascertain the possibilities of the existing information system and to make the necessary adaptations in it. Some respondents said that they had used Excel for making auxiliary files.

Owing to the fact that IAS/IFRS does not present a binding form for the statements, the necessary accounting statements had to be designed.

The result of this stage was a simulation of IAS/IFRS methods for the previous period and making a model annual report.

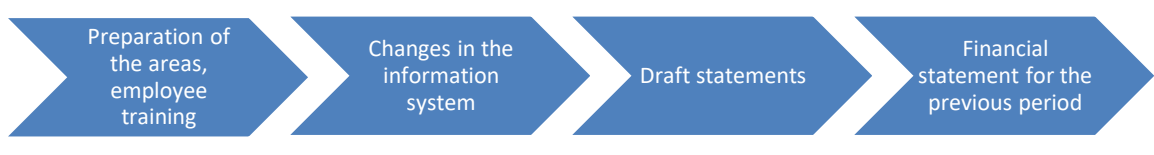

Fig. 3. Stage 2 - Opening Stage.

In the 3rd stage of project implementation (Fig. 4), trial operation was launched to test the new methods and to eliminate errors. The result of the trial operation was an opening balance sheet.

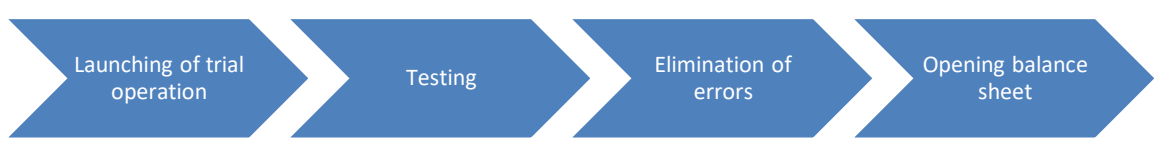

Fig. 4. Stage 3 - Trial Operation.

In the final stage of implementation, adaptation operation was launched (Fig. 5). Having been launched, the adaptation operation was constantly checked and evaluated and possible minor mistakes corrected.

When questioned whether they had been making mistakes in the first years, 9 respondents answered that they had, but 4 of them added that they had been only minor issues, inaccurate estimates and irrelevant mistakes. 3 respondents were not aware of any errors.

The most frequent errors included wrong methods of appraisal or reporting of data in incorrect parts of the statements. Other mistakes mentioned during the interviews included falsely reported profits on the sale of own shares in the P\&L statement, mistakes in the use of hedge accounting, consisting in not complying with the conditions, and ignoring the principle of priority of substance over form. 


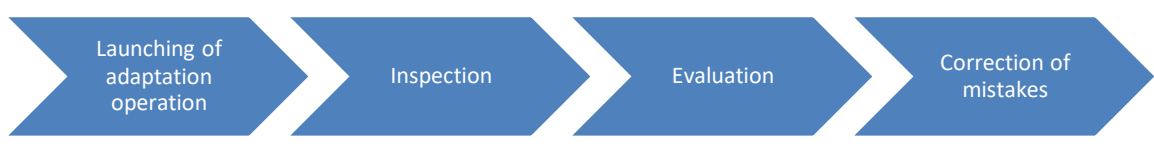

Fig. 5. Stage 4 - Adaptation Operation.

Regarding the duration of the implementation it was researched that the smaller units had taken about 3 months, and in the larger units it had been from 15 to 18 months. There was even an answer that the implementation process took only a few weeks. It was also said that the implementation process had been ongoing since 2013 and was steadily improving. Frequency of the answers is in Table 2.

Table 2. The duration of the IAS/IFRS implementation.

\begin{tabular}{|c|c|}
\hline The duration of the IAS/IFRS & Frequency of answers \\
\hline Max. 1 month & 1 \\
\hline Max. 6 months & 3 \\
\hline Max. 1 year & 8 \\
\hline More than 1 year & 4 \\
\hline
\end{tabular}

\section{Conclusion}

IAS/IFRS implementation is a multi-stage process taking months, at the minimum, but even more than a year.

Companies should get ready for the transmission from national accounting rules to IFRS sufficiently in advance [14].

The basis for successful implementation is a project plan including a work schedule.

During the process of IAS/IFRS implementation, it is necessary to create a highquality team because the process requires cooperation of experts in the field of accounting, legislation and computing.

Besides sufficient time and number of qualified staff, it is necessary to secure financial resources because IAS/IFRS implementation involves a change in the information system of the business.

The process of IAS/IFRS implementation can be managed well only if all the necessary inputs, including a high-quality project plan, are respected. 


\section{References}

1. De Jong, A., et al.: The economic consequences of IFRS: the impact of IAS 32 on preference shares in the Netherlands. Accounting in Europe, 3 (2), 196-285 (2016).

2. Dvořáková, D.: Finanční účetnictví a výkaznictví podle mezinárodních standardů IFRS. Brno: Computer Press (2009).

3. Epstein, B.J., Mirza, A. A.: Wiley IAS 2003: Interpretation an Application of International Accounting Standards. John Wiley \& Sons (2003).

4. European Union. Právo EU a související dokumenty. Retrieved January 25, 2017, from: http://eur-lex.europa.eu/homepage.html?locale=cs (2016).

5. ICAEW. EU Implementation of IFRS. Retrieved January 25, 2017, from http://www.icaew.com/ /media/corporate/archive/files/technical/financial\%20reporting/fin ancial\%20reporting\%20faculty/executive\%20summary.ashx (2007).

6. International Financial Reporting Standards. London: IASB. (2009).

7. Jermakowicz, E.K., Gornik-Tomaszewski, S.: Implementing IFRS from the perspective of EU publicly traded companies. Journal of International Accounting, Auditing and Taxation, 15 (2), 170-196 (2006).

8. Jílek, J., Svobodová, J.: Účetnictví podle mezinárodních standardů účetního výkaznictví (IFRS) 2013. Praha: Grada Publishing (2013).

9. Kovanicová, D.: Abeceda účetních znalostí pro každého. Praha: Bova polygon (2008).

10. Oremusová, P.: Meritum téma: Účetní závěrka 2007. Praha: Wolters Kluwer (2007).

11. Pravat, I.C.B., Diaconu, D.: News and insights on the convergence of IFRS - U.S. GAAP. Studies and Scientific Researches: Economics Edition 0(18), (2014).

12. PrivatWaterhouseCoopers (PWC). The transition from local GAAPs to International Financial Reporting Standards. Retrieved January 25, 2017, from http://www.pwc.com/hu/en/services/ifrs/ifrs_szolgaltatasok.html (2006).

13. Rotila, A. Patrut, V.: Standardisation and professional judgment in the accounting practice. The Annals of the University of Oradea, Economic Sciences Series, 3 (17), (2008).

14. Šrámková, A., Janoušková, M.: Mezinárodní standardy účetního výkaznictví. Praha: Institut svazu účetních (2008).

15. Strouhal, J., et al.: Velká kniha př́kladů. Brno: BizBooks (2012).

16. Syahdan, S. A., Safriansyah, S., Lisandri, L.: International financial reporting standards (IFRS). Jurnal Riset Akuntansi dan Keuangan, 1(3), 215-229 (2017).

17. Zasadnyi, B.: Analysis of the implementation of International financial reporting standards by countries with economies in transition. Visnik. Kiivskogo Nacionalnogo Universitetu imeni Tarasa Ševčenka, 8 (150). 94-98 (2014). 